\title{
Schiță de critică morală a transumanismului ateu din perspectiva bioeticii creștine a lui T.H. Engelhardt
}

\author{
Andrei DÎRLĂU*
}

Motto:

După transcendență, după Dumnezeu, nu mai este nicio perspectivă secularistă canonică. Nu există niciun substitut rațional canonic pentru perspectiva ochiului-lui-Dumnezeu.

H.T. Engelhardt, After God

Aș vrea să existe un Dumnezeu care să-mi vadă situația și să-mi spună: Asta ar trebui să faci!

Julian Savulescu

Totul se prăbușește; centrul nu mai ține William Butler Yeats, Second Coming, 1919 (despre venirea Antihristului)

„,Tot ce e posibil e legitim” (???)

Abstract: Sketching a moral criticism of atheist transhumanism from the perspective of H. T. Engelhardt's Christian bioethics. There are presented the definitions and pretensions of the utopic and atheistic ideology called "transhumanism"; the differences between "transhumanism" and "posthumanism". There are discussed the moral criteria that should guide

* Scriitor, Doctor în Teologie al Facultății de Teologie Ortodoxă, Universitatea „1 Decembrie 1918" din Alba Iulia, România. 
transhumanism and their lack of foundation. With arguments from Christian bioethics, philosophy, and theology from H. T. Engelhardt's book After God, it is proven that secularistic morality has no canonical foundation, being grounded upon a perspective that is immanent, arbitrary, "out of nowhere"; lacking an ultimate referential and transcendent framework, so having no absolute validity. Such morality is contingent, and it has no objectivity, impartiality, unicity, canonicity, and a universal imperative character. Its consequences are serious: atheist morality is weakened, reduced to a simple political agenda, without being able to legitimate a rule according to higher law, only one that is secularistically fundamentalist. Atheist transhumanism is marked by serious ethical shortages even in its own philosophical grounding. There is the major risk that a society without God collapses, since man cannot survive in a dysteleologic world without an ultimate, transcendent finality. Technology without valid ethical criteria risks destroying humanity. Christian transhumanism is an alternative to the atheist one, but within the limits that pertain to the conflict that resides between their different methodological postulations. Even if Romania does not confront with transhumanistic ideology yet, in the future this ideology will not be late in manifesting itself, as new technology will change our lives and mass media will expose to newer generations transhumanistic ideas in a veiled and not so veiled manner.

Keywords: Posthumanism, ideological utopia, moral pluralism, rational and impartial observer, canonical morality, God's-eye view, moral law, imperative character, angry nihilism, dysteleology.

\section{Transumanism și postumanism: utopie și criterii (i?)morale}

Transumanismul, așa cum îl înțelege Max More, care a și introdus acest termen în $1990^{1}$, este o filosofie ce-și propune să călăuzească omenirea spre o condiție post-umană (cea a unor hibrizi bio-tehnologico-digitali gen cyborgi sau androizi din filmele SF). El dorește continuarea și accelerarea evoluției vieții inteligente dincolo de actuala ei formă umană şi de limitele

${ }^{1}$ Prima dată termenul apare în Divina Comedie a lui Dante Alighieri (,trasumanar” - Paradiso, Canto I, 70, în Commedia, a cura di Giorgio Petrocchi, Mondadori, Milano, 1966, p. 299). 
acesteia cu ajutorul științei și tehnologiei. Folosirea acestor mijloace, susține el, va permite în final omului să depășească ceea ce se înțelege azi prin „omenesc"

Există o diferență între „transuman” și „postuman”. Termenul „transuman” desemnează doar omul „moderat augmentat", adică beneficiind doar de un număr limitat de „protezări” sau ,augmentări” tehnologice care i-ar conferi câteva capacități superioare celor ale omului încă „ne-augmentat”. Dar transumanul ar fi doar o fază de tranziţie. Faza finală ar urma să fie cea „postumană” a unor entităţi „deplin augmentate”, incomparabil „superioare speciei umane pe scara evoluției”, înzestrate cu ,superinteligență artificială” și - speră transumaniști ca Nick Bostrom ${ }^{3}$ - nemurire. În această direcție se îndreaptă cercetările companiilor GAFA (Google, Apple, Facebook, Amazon). În diagrama de mai jos se observă anti-umanismul lui Bostrom, reflectat în dimensiunea minusculă a zonei de posibilități sau performanțe atribuită de el omului, mai mică chiar decât cea alocată animalelor şi incomparabil mai mică decât a trans- şi postumanilor. De altfel, transumanismul consideră că speciei umane i se acordă prea multă atenție și numesc „rasism uman” sau „specierasism" sapiens în raport cu regnul animal sau vegetal ori cu viitoarele presupuse entități postumane.

Tehnologia, vrea să ne convingă Bostrom, va rezolva toate problemele omenirii. Boala, sărăcia, distrugerea mediului, suferința vor fi eliminate $\mathrm{cu}$ ajutorul nanotehnologiilor avansate de către super-I.A. (inteligența artificială). Superinteligența va prelungi indefinit viața omului, oprind îmbătrânirea prin nanomedicină și/sau oferind o ,nemurire” virtuală prin „transferarea minţii” umane (mind uploading) pe suport digital, și

2 Max MORE, Transhumanism. Towards a Futurist Philosophy, 1990, http://www.maxmore.com/transhum.htm.

3 Nick Bostrom, Transhumanist Ethics, https://nickbostrom.com/ethics/ transhumanist.doc.

4 What is Transhumanism? Humanity+. Transhumanist FAQ, https:// whatistranshumanism.org/\#what-is-transhumanism. 
va face posibilă o creștere enormă a capacităţilor intelectuale. Omul va trăi, într-o lume ideală, o viață plină de bucurie și plenitudine dedicată relației umane cu ceilalți, experiențelor și creșterii personale şi atingerii idealurilor ${ }^{5}$. Este o descriere perfectă a utopiei.

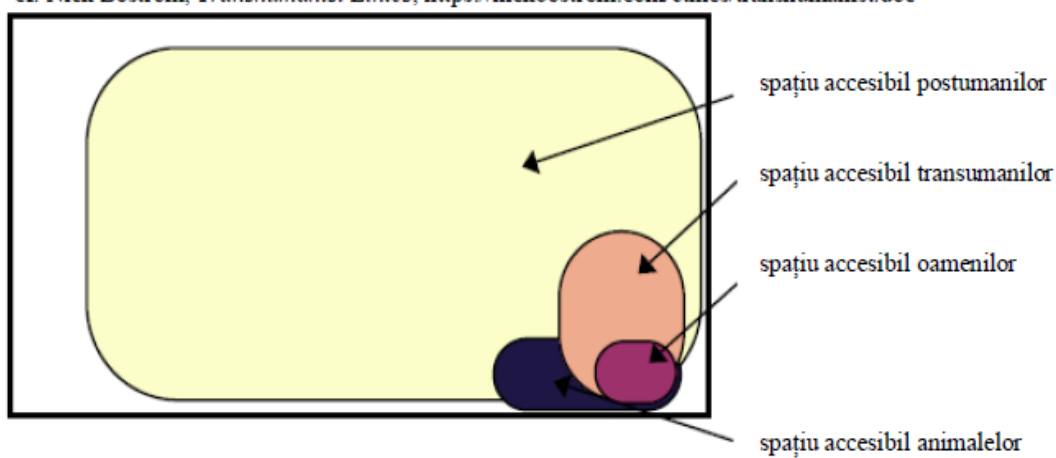

Există în literatura pe această temă un consens că tehnologia „bună” (folosită benefic, moral) trebuie distinsă de cea „rea” (folosită distructiv, nefast, imoral). Disputa din jurul transumanismului vizează locul unde trebuie plasată granița dintre ele. Pe de o parte, susținătorii transumanismului încearcă să împingă această limită cât mai jos posibil, în direcția acceptării tehnologiilor celor mai revoluționare, mai progresive cu putință, cât mai aproape de permisivitatea totală. Ei pledează pentru minimalizarea riscurilor percepute, argumentând că riscurile merită luate dacă nu sunt ,extreme” (dar ce criterii definesc extremul?). Adversarii lui împing limita cât mai sus posibil, către o abordare precaută, selectivă, şi respingerea tehnologiilor nedovedite ca fiind sigure. De dragul siguranței, ei pledează pentru maximizarea riscurilor percepute. Asemenea distincții pot părea teoretice, academice, simple chestiuni de

${ }^{5}$ Nick Bostrom, Transhumanist Values, Philosophy Documentation Center, 2005, www.nickbostrom.com (accesat la data de 14.03.2020). 
accent şi grad; dar e posibil ca viitorul nostru ca specie să depindă de ele. Riscurile nu țin de tehnologiile în sine, ci de confuzia care generează proliferarea negestionabilă de criterii ce ar trebui să ghideze alegerile și deciziile privind tehnologia, și de consensul (real sau mai adesea fals) invocat pentru a legitima aceste criterii.

Putem decide în mod rațional unde trebuie trasă linia între cele două şi cine are dreptul să tragă această linie? Pentru a lua asemenea decizii avem nevoie să le întemeiem pe criterii valide. Consider cuvântul „,criterii” a fi termenul-cheie al întregii dezbateri etice din jurul transumanismului. „Bun/rău” sunt termeni morali, fiind necesare criterii morale. Desigur, criteriile trebuie să fie raționale. Dar este rațiunea umană suficientă? Pot fi definite aceste criterii exclusiv pe cale rațională, pe baza rațiunii umane, fără apel la o instanță transcendentă?

Studiul de față răspunde negativ la această întrebare. Iar fără criterii etice valide, tehnologia riscă să distrugă omenirea.

Multe dintre problemele ridicate de transumanism sunt inerent legate de bioetică. De aceea, în discutarea acestor chestiuni privind dezbaterea etică asupra transumanismului, abordarea mea va folosi argumente din bioetica creștină, filosofie și teologie, împrumutate din ultima carte a profesorului H.T. Engelhardt, After God. $\mathrm{Nu}$ voi intra în aspecte tehnice specializate, tratate în numeroase studii transumaniste ${ }^{6}$, interesul meu nefiind tehnologiile

${ }^{6}$ Fac aici o singură excepție, cu rol ilustrativ, dând un exemplu tehnic din domeniul biotehnologiilor: recenta controversă privind editarea genomului uman. Studiile arată că metoda CRISPR-Cas9 de segmentare a ADN-ului poate produce adevărate ravagii genetice, inclusiv ștergerea imprevizibilă a unor componente ducând la ,amuțirea” unor gene care ar trebui să fie active, de pildă cu rol în mecanismele anti-cancer, sau activarea altora care ar trebui să fie „mute”, de pildă care pot cauza tumori canceroase (https://blog.petrieflom.law.harvard.edu/2018/08/14/can-a-national-

conscience-be-gene-edited/; www.statnews.com/2018/07/16/crispr-poten tial-dna-damage-underestimated/). Implicațiile bioetice sunt evidente, nemaivorbind de discriminarea, nedreptățile și dezavantajele ce rezultă din disponibilitatea biotehnologiilor scumpe doar pentru cei avuţi, nu și pentru populația săracă. 
ca atare, ci premisele şi presupozițiile morale fundamentale ale trans-umanismului.

Pledoaria mea nu este nici pentru acceptarea totală a tehnologiei, care ar fi periculoasă, nici pentru interzicerea ei totală, care ar fi absurdă și imposibilă, ci pentru discernământul responsabil ghidat atât de criterii raționale, cât și de cele ale moralei creștine. $\mathrm{Nu}$ pentru pesimism ori scepticism, ci pentru precauție, luciditate, înţelepciune şi credință.

\section{Observatorul rațional „imparțial” al lui Kant ${ }^{7}$}

Pentru discernământ avem nevoie de criterii valide. Dar se ridică întrebarea: cum se poate ajunge la o validitate universal recunoscută? În ultimă instanţă, o asemenea validitate nu poate fi doar una instrumentală, utilitaristă, ci una morală. Ceea ce duce la chestiunea fundamentului pe care se pot întemeia asemenea criterii pentru a le asigura validitatea morală. Deoarece pentru a pretinde o validitate morală universal acceptată, aceste criterii trebuie să fie fundamentate pe anumite premise. Căci orice filosofie morală anume presupune totdeauna un set de premise de bază, dinainte convenite și agreate, pentru a fundamenta concluziile pe care vrea să le demonstreze. $\mathrm{Cu}$ alte cuvinte, e nevoie de o anume perspectivă asupra unei anume raționalități morale care să-i călăuzească pe toți spre o morală canonică, unică. Pe o asemenea perspectivă se va putea întemeia un punct de vedere rațional imparțial care să-i dea substanță. Adoptând-o, un observator rațional imparțial va putea face alegeri ori lua decizii întemeiate. La un asemenea observator rațional imparțial [ein vernünftiger unparteiischer Zuschauer] recurge Immanuel $\mathrm{Kant}^{8}$.

7 Acest argument Kantian este adus de profesorul H. Tristram ENGELHARDT în ultima sa carte, After God. Morality and Bioethics in a Secular Age, Yonkers, New York, St. Vladimir's Seminary Press, 2014, p.13 (în curs de traducere în lb. română). În continuare pe parcursul întregului studiu am urmat liniile demonstrației acestui important filosof și bioetician citându-i principalele argumente.

${ }^{8}$ Immanuel KANT, The Foundations of the Metaphysics of Morals, transl. Lewis 


\section{Există o morală secularistă ,canonică universală comună" pe care s-o poată invoca transumanismul?}

Observatorul [Zuschauer] rațional imparțial al lui Kant ar fi presupusa călăuză care să-i orienteze pe toți către o presupusă morală canonică unică, imparțială, obiectivă, comună, universal recunoscută și deci cu caracter imperativ universal, respectiv o bioetică întemeiată pe această morală. Căci altfel, fără acest observator, morala și bioetica ar fi plurale în mod negestionabil.

Dar poate fi o morală canonică întemeiată pe cale pur raţională? Poate exista un asemenea punct de vedere raţional imparţial? Îi poate raţiunea călăuzi pe toţi către o morală unică şi o bioetică canonică unică? Desigur că nu. Kant a recurs la observatorul raţional imparţial pentru a întemeia şi a da substanţă perspectivei sale morale. Dar postularea, în cadrul orizontului a ceea ce este finit şi imanent, a unei perspective de nicăieri, care să poată călăuzi în mod neutru şi canonic morala și bioetica, e o speranță deșartă. Nu poate exista o perspectivă de nicăieri.

O ,morală unică, obiectivă, imparțială, comună tuturor, canonică, universal recunoscută" ar trebui întemeiată pe o perspectivă neutră, nepărtinitoare. Dar este ea posibilă? Steven Smith afirmă că nu există perspectivă neutră, nepărtinitoare: „căutarea neutralității e încercarea de a apuca o iluzie",9.

Principiul moral universal spune: „Fă binele!”. Dar care e „binele”? La fel: ce e „drept”, ce e ,virtuos”? Pentru ca un decident sau observator raţional să-i călăuzească pe alții, să facă o alegere ori să ia o decizie morală întemeiată, el trebuie să aibă deja un simţ moral sau o teorie a binelui, fie măcar şi unul vag. Or, asta înseamnă că el nu poate fi imparţial, ci dimpotrivă, că trebuie să fie de la început adeptul unui anume sens privind ceea

White Beck, Indianapolis, Bobbs-Merrill, 1959, p. 9 (Akademie-Ausgabe AK IV.393, Preussische Akademie der Wissenschaften, Berlin, de Gruyter, 1902), apud H.T. ENGELHARDT, After God..., p. 14.

9 Steven D. SMith, Foreordained Failure: The Quest for a Constitutional Principle of Religious Freedom, New York, Oxford University Press, 1995, p. 96, apud ENGELHARDT, After God..., p. 14. 
ce e raţional din punct de vede moral. Adică dispune de un anume conţinut moral pentru a-l ghida. Dar care e acela? Ce anume perspectivă asupra a ce e moral din punct de vedere raţional ar trebui să adopte ipoteticul decident ori observator raţional? Chiar dacă toți oamenii ar prețui aceleași bunuri, nefăcând decât să le ierarhizeze diferit, punându-le în altă ordine, deja prin asta ar constitui morale diferite. Cum ar trebui ierarhizate valori umane cruciale precum libertatea, egalitatea, prosperitatea, siguranţa, şi de ce? Ierarhizări diferite ale acestor valori duc la viziuni morale și bioetice diferite.

Rorty recunoaște și el că „nu există niciun fel de criterii imparțiale la care să se poată face apel, dincolo de meritele relative ale diverselor comunități reale ori propuse" ${ }^{\prime 10}$. Pentru a putea dezvolta o anume argumentare pe care să se poată întemeia drept canonică o anumită perspectivă asupra a ceea ce e raţional din punct de vedere moral, trebuie să se admită în prealabil un cadru format din anumite premise de bază şi reguli de acceptare a dovezilor. Dar dacă acest cadru este supus relativismului și controverselor, pus în contrast cu o mulţime de alte cadre de referinţă formate din alte premise și reguli de acceptare a dovezilor, atunci va fi imposibilă ajungerea la un anume conținut moral ori ierarhizare corectă, căci va fi imposibilă evitarea perpetuei puneri sub semnul întrebării, a argumentării în cerc, a regresiei logice infinite şi aşa mai departe la nesfârşit. Așadar, nu există niciun substitut raţional pentru perspectiva „ochiului lui Dumnezeu”. Orice morală care are un conţinut este una anume, fiind ca urmare în contrast cu multe altele. În absența lui Dumnezeu şi a unui standard moral canonic, plin de conținut, chiar și încercarea lui Kant de a întemeia un conținut canonic al moralei ca act al rațiunii, unic și necondiționat istoric, a eșuat: întotdeauna va fi nevoie de presupoziția unei anume concepții-cadru de referință privind modul în care să fie agreate și ierarhizate valorile umane cardinale, a unui anume set de premise de bază și reguli de acceptare a dovezilor ${ }^{11}$.

10 Richard RORTY, Objectivity, Relativism, and Truth, New York, Cambridge University Press, 1991, p. 197, apud ENGELHARDT, After God..., p. 14.

${ }^{11}$ H. Tristram EngELHARDT, After God ..., p. 14. 
Așadar, „în ciuda aspirației Kantiene aflate în miezul Iluminismului, nu există observator rațional imparțial. În absența unui standard canonic, o morală devine nimic mai mult decât un anume mănunchi de intuiții morale sprijinite de una dintr-o pluralitate de naraţiuni morale. $\mathrm{Nu}$ se poate întemeia un standard moral canonic secularist, deoarece pentru a stabili un anume standard normativ drept canonic, e nevoie de un alt standard normativ de referință. Pentru a asigura canonicitatea unei anume teorii a binelui ori perspective a unui ipotetic judecător, observator ori decident moral dezinteresat, unei raționalități ori sens moral, e nevoie de un alt standard de referință, în raport cu care să fie ordonate canonic condițile de bază ale dreptului, valorile și bunurile morale cardinale etc." 12 .

Proiectul filosofic al Iluminismului și al Revoluției Franceze a fost de a întemeia morala pe rațiunea secularizată, nu pe credinţă. Filosofia morală a promis un sistem moral validat rațional care să poată constitui o lingua franca morală canonică, un discurs moral acceptabil de toți. O morală canonică universală, comună, poate fi obținută prin argumente raționale sănătoase. Dar acest proiect intelectual a eșuat. $\mathrm{Nu}$ există o morală secularistă comună, imperativă pentru toți oamenii, toate culturile și religiile.

\section{Morala secularistă, inclusiv transumanistă, este lipsită de temeiuri}

De mult s-a înțeles că e imposibil a întemeia pe demonstrație rațională o anume morală drept canonică. Clement al Alexandriei a arătat că demonstrația rațională nu poate furniza concluzii cu caracter imperativ decât dacă sunt mai întâi acceptate niște premise iniţiale de referință: „Dacă va spune cineva că știința, în unire cu rațiunea, poate demonstra orice, atunci acela să audă că principiile, cauzele primare ale existenței, nu pot fi demonstrate; nu pot fi cunoscute nici cu ajutorul artei, nici cu ajutorul rațiunii"13.

${ }^{12}$ H. Tristram EngelHaRd, op. cit., p. 73.

13 Clement Alexandrinul, Stromatele, II, cap. IV, 13.4, în Scrieri, trad. D. Fecioru, PSB 5, București, Edit. Institutului Biblic și de Misiune al Bisericii Ortodoxe Române, 1982, p. 120. 
Se poate astfel arăta că acest impas e în principiu inevitabil, întrucât orice asemenea pretenții implică existența unor standarde călăuzitoare inițiale. Profesorul Engelhardt îl descrie astfel:

„Kant a înțeles că fără Dumnezeu nu e posibilă întemeierea moralei pe o raționalitate canonică. Emiterea unor teorii ca dreptul natural ori drepturile omului nu ajunge pentru a contracara răspunsul «imoralistului» că $n u$ e totdeauna rațional să acționezi moral. E nevoie atât de o perspectivă a ochiului lui Dumnezeu cât și de Dumnezeu ca garant că în final oamenii vor fi fericiți proporțional cu vrednicia lor de a fi fericiţi. Ambele condiții sunt esențiale pentru a păstra tradiționala coerență a moralei. Fără Dumnezeu n-ar fi totdeauna rațional să acționezi potrivit imperativului categoric al lui Kant - norma morală universalizantă a agenților raționali. Kant afirmă că e nevoie de perspectivaochiului-lui-Dumnezeu și nemurire [înțeleasă teologic, nu transumanist] pentru a păstra forța și raționalitatea conținutului canonic promis de morala europeană occidentală. Kant L-a plasat pe Dumnezeu în centrul sistemului său, ca piatră de temelie, argumentând că existența lui Dumnezeu, nemurirea și liberul arbitru, trebuie afirmate ca postulate ale rațiunii practice pentru a asigura moralei un conținut canonic, a menține coerența rațională a binelui și a dreptului și a garanta întâietatea moralei asupra prudenței" 14 .

Căci, într-adevăr, un om imoral acuzat că se comportă imoral poate răspunde că, într-un univers lipsit de orice sens ultim, voința sa de a-și urmări propriile țeluri și interese egoiste e la fel de îndreptățită ca oricare alta dintr-o mulțime de puncte de vedere la fel de ,normative” și cu tot atâta ,autoritate”.

Kant a încercat să întemeieze morala pe o raționalitate morală congruentă cu perspectiva ochiului-lui-Dumnezeu, astfel încât să consolideze o morală canonică ancorată în ființă prin demonstrație filosofică. Miza nu e teama de Dumnezeu ca motivație pentru a te comporta moral, ci Dumnezeu recunoscut ca izvor al sensului ultim

${ }^{14}$ H. Tristram ENGELhardT, op. cit., p. 79. 
al moralei, al coerenței raționale a binelui și dreptății și al necesarei întâietăți a alegerii morale față de alegerea prudentă. Kant a înțeles că dacă aceste condiții nu sunt respectate, morala ar înceta să aibă conținut canonic unic și forță imperativă rațională ori întâietate incontestabilă asupra considerentelor normative non-morale ${ }^{15}$. Pentru Kant, Dumnezeu este temeiul legii morale unice și coerente:

„Există un Dumnezeu [...] care este dătător al legii morale.

Căci rațiunea dătătoare a legii morale exprimă prin imperativul categoric îndatoririle"16.

Morala secularizată este lipsită de orice ancoră în fiinţă ori într-o raţiune morală canonică (împreună cu bioetica aferentă ei). Ambele sunt solidare cu o cultură marcată de dispute profunde, fără niciun punct de referință ultim. Rădăcinile epistemologice şi metafizice ale moralei și bioeticii de azi, pe care mulți le-au crezut accesibile prin întemeierea pe raţiunea morală, se dovedesc inexistente. Odată ce L-ai abandonat pe Dumnezeu și încerci să trăieşti „după Dumnezeu”, ca şi când totul ar fi lipsit de înţeles ultim, eşti dus în derivă în orizontul finitului şi al imanentului. Morala și bioetica secularizată nu pot fi ceea ce se speră.

Se poate încerca evitarea impasului de mai sus apelând la morală ca presupus fenomen natural format odată cu evoluţia oamenilor. Dar nici asta nu ajută, deoarece pentru a fundamenta niște concluzii normative ar trebui precizate ,țelurile" evoluției și mediul de referință. Pentru a emite o judecată morală e nevoie de un etalon, un standard. Dar ce etalon? Alegerea presupune stabilirea unor premise și reguli de acceptabilitate a argumentelor. Rămâne întrebarea: care anume? Dacă am adopta un punct de vedere evoluționist, am avea nevoie mai întâi să indicăm un anumit context și direcția evoluției. Din nou ne confruntăm cu aceeași problemă. Pentru a da un răspuns importăm un anume punct de vedere ${ }^{17}$.

\section{Ibidem.}

${ }^{16}$ Immanuel Kant, Opus Postumum, ed. Eckart Förster, transl. E. Förster \& M. Rosen, Cambridge University Press, 1993, p. 204. (AK XXII, 122-123), apud ENGELHARDT, op. cit., p. 79.

${ }^{17}$ H. Tristram EnGELHARDT, op. cit., p. 81. 
Seculariștii (inclusiv majoritatea transhumaniștilor) prezumă un substitut rațional al perspectivei ochiului-lui-Dumnezeu. Dificultatea este că nu există standarde morale seculariste canonice; asemenea fundamente nu există. Fără Dumnezeu nu există decât nisipurile mișcătoare ale speculațiilor morale lipsite de temeiuri în care ne scufundăm.

\section{Pluralismul moral negestionabil. Morala „comună” a transumanismului - una dintre multe altele}

În absența unui punct de referință ultim, a unei perspective finale care să se ridice deasupra mulțimii de opinii morale concurente și să impună o anume morală drept canonică, morala devine în mod negestionabil plurală: pluralismul moral câștigă. $\mathrm{Nu}$ există o unică morală (și bioetică) seculară canonică; ele sunt legiune. Nu există niciun argument rațional ori standard obiectiv care să poată fi adoptat de toți și legitima o anume morală secularizată drept canonică. Ceea ce se pretinde a fi normativ, rațional din punct de vedere moral ori rezonabil din punct de vedere politic, se dovedește a nu fi decât o perspectivă contingentă printre multe alte perspective morale la fel de contingente. $\mathrm{Nu}$ se poate ieși din această dificultate nici apelând la contractele sociale, care sunt și ele plurale și a căror autoritate e și ea pusă în discuție odată ce s-au pierdut temeiurile prime.

Întrucât se evită referința la un Dumnezeu transcendent, morala e recunoscută ca fiind pe deplin condiționată socio-istoric, ca urmare căzând în orizontul finitului și al imanentului. Din acest motiv narațiunea culturală secularizată dominantă, inclusiv oricare morală seculară, e totdeauna doar un discurs printre altele ce plutesc liber, fără nicio ancoră, condiționate socio-istoric în orizontul finitului și al imanentului. Toate moralele seculariste sunt doar nori de intuiții morale fără fundament, sprijinite pe anumite narațiuni morale, ce pot fi în cel mai bun caz privite ca reprezentând câte o poziție morală autonomă printre multe altele. Odată ce Dumnezeu a încetat a mai fi recunoscut, totul în cele din urmă plutește liber, fără ancoră ontologică ori într-o raționalitate canonică. 
Postmodernitatea este recunoașterea culturală că raţiunea secularizată nu poate furniza o morală, narațiune, gramatică sau reprezentare a realității care să fie canonică și universală și să-L poată înlocui pe Dumnezeu. $\mathrm{O}$ asemenea reprezentare canonică universală a fost speranța modernității. Ea a fost promisă de proiectul moral-filosofic Apusean, fiind luat ca de la sine înţeles. Modernitatea credea că rațiunea era una, așa cum Dumnezeu fusese înainte recunoscut ca Unul. Iluminismul fusese construit pe această credință în raţiune. În postmodernitate această credință e recunoscută ca nefondată. Se admite astfel deschis ceea ce a fost dintotdeauna adevărat privind reprezentările seculariste ale moralei și realității - pluralitatea lor entropică.

Bioeticieni influenți ca Beauchamp and Childress pretind că ar exista o morală comună - pretenție ce intră în conflict cu efectiva pluralitate negestionabilă de viziuni morale şi bioetici ${ }^{18}$. Versiunea lor bioetică e în mod limpede imposibil de susţinut. Cum recunoaşte chiar Beauchamp, însăşi teoria bioetică e pusă sub semnul întrebării în mod radical.

Post-modernitatea afirmă ca postulate pluralismul moral ireductibil şi absenţa din cultura secularizată a unei perspective a ochiului-lui-Dumnezeu argumentată raţional şi a oricărui sens ultim al lumii. Proliferarea perspectivelor morale secularizate devine inevitabilă. Filosofia secularizată nu o poate transcende, și nici contextul post-modern în care ne aflăm. Morala care în trecut era ancorată în Dumnezeu e acum desprinsă, în derivă. În schimb abundă moralele și bioeticile seculariste slabe.

La rădăcina post-modernității stă recunoașterea inevitabilității pluralismului moral secularizat și pierderea oricărui punct de orientare ultim, transcendent.

\section{Demoralizarea, deflația, ,slăbirea" și secularizarea radicală a moralei}

Kant înțelegea că pentru ca punctul de vedere moral să aibă întâietate e nevoie de Dumnezeu, Care Își definește și impune

18 Tom Beauchamp \& James Childress, Principles of Biomedical Ethics, New York, Oxford University Press, 1979, apud EnGELHARDT, op. cit., p. 81. 
perspectiva morală. Morala Kantiană, la fel ca și creștinismul tradițional, are un set de norme considerate a-și avea obârșia într-o perspectivă canonică obiectivă. Morala lui Kant susține afirmații pe care cultura dominantă secularizată de azi le-ar caracteriza drept ,intolerante, fundamentaliste”. Kant este ultimul mare fundamentalist moral-filosofic. Însuși sensul moralei creștine și Kantiene e altul decât cel al culturii dominante secularizate. $\mathrm{O}$ bioetică Kantiană e incompatibilă cu bioetica secularizată dominantă azi. Prin contrast, moralele culturii dominante seculariste de azi sunt seturi de norme fără alt temei decât cel al unor țesături autonome de intuiţii morale susţinute de narațiuni articulate în întregime în orizontul finitului și al imanentului, având ca urmare consistență morală redusă. Prin postulatele lui Dumnezeu și al nemuririi, Kant dorea să-și legitimeze ateismul, dar păstrând și morala creștină tradițională occidentală. Hegel a considerat că acest lucru nu este posibil ${ }^{19}$.

19 Hegel vorbea despre moartea culturală a lui Dumnezeu, înțelegând că astfel morala secularizată a Apusului nu mai putea avea decât un sens imanent, condiționat socio-istoric (Glauben und Wissen, orig. in Kritisches Journal der Philosophie, vol. 2, No.1, Tübingen: Cotta, 1802, apud H. Tristram ENGELHARDT, op. cit., p. 81.). El articulează o reprezentare filosofică postmetafizică, dându-și seama că proiectul moral-filosofic de a păstra o morală canonică secularizată cu conţinutul moralei creștine tradiționale pe baza unei demonstrații raționale nu va putea reuși. El prezice imanentizarea radicală a moralei și a realității umane, împreună cu cea a idealurilor ce definesc realizarea și împlinirea umană, înțelegând că nicio morală secularizată nu poate fi văzută decât ca o morală contingentă, determinată socio-istoric, printre multe altele, una dintre numeroasele Sittlichkeiten (G.W.F. HEGEL, Faith and Knowledge, trans. Walter Cerf, H. S. Harris, Albany, State University of New York Press, 1977, p. 190, apud H. Tristram ENGELHARDT, op. cit., p. 81). Dacă nu mai e recunoscută existența lui Dumnezeu Care răsplătește acțiunea dreaptă și o pedepsește pe cea nedreaptă, atunci statul e în mod implicit cel mai bun înlocuitor al Lui de care dispunem pentru a da recompense și sancțiuni morale. Pentru Hegel, statul este „marşul lui Dumnezeu prin lume [der Gang Gottes in der Welt, dass der Staat ist]". Statul devine „Dumnezeul efectiv” [der wirkliche Gott] (Hegel 1991, p. 279, §258 Zusatz). În absența unei morale canonice, cea mai bună aproximare a ei este instituirea unei morale prin intermediul dreptului, al legislației și al politicilor publice, adică al statului. 
Bioeticienii cu orientare tradiționalistă vorbesc despre războaiele culturale contemporane ${ }^{20}$ și nevoia de a ,remoraliza spaţiul public".

Există încercări de a legitima morala comună secularizată, dar atât de slabe încât sunt comice. Beauchamp şi Childress pretind că ,morala umană comună e acea morală universală împărtășită de toți oamenii serioși din punct de vedere moral'". Dar seriozitatea morală e doar o expresie retorică intenționat vagă. Același lucru se aplică definiției la fel de neclare pe care ei o dau moralei comune ca „setul de norme împărtășite de toți oamenii angajați moral (hotărâți să fie morali)"21. Cine și cum decide cine sunt acei oameni? Câți și care sunt acei oameni și ce norme trebuie să respecte ei pentru ca acele norme să fie recunoscute, și de cine, drept morală comună? De fapt, e evident că morala s-a prăbuşit într-o pluralitate de morale aflate în competiție între ele, niciuna dintre ele nefiind universal imperativă. În sfera imanentului, politicul este adevărul mai înalt al moralei secularizate. De-moralizarea a devenit parte a unei agende politice seculariste.

Respingând iluzia că după Dumnezeu morala ar mai putea fi ceea ce a fost, G. Anscombe arată că sensul unei morale ,postcreștine" e atât de radical schimbat încât se articulează în termeni non-morali: însuși termenul „moral” ar trebui abandonat ${ }^{22}$. Și Nietzsche admitea că, după „moartea” lui Dumnezeu, morala devine o ficțiune în cel mai bun caz, neavând nici statut canonic, nici sens peren (Despre genealogia moralei, 1887). Însuși sensul moralei trebuie radical reconsiderat.

Morala și bioetica dominante azi, inclusiv cele invocate de transumanism, sunt lipsite de temei sau ancoră canonică, demoralizate, ,slăbite”, radical secularizate.

${ }^{20}$ Mark CHERry, Sex, Family, and the Culture Wars, New Brunswick and London, Transaction Publishers, 2016.

21 Tom Beauchamp \& James Childress, The Principles of Biomedical Ethics, $7^{\text {th }}$ ed., New York, Oxford, 2012, 417.

${ }^{22}$ G.E.M. Anscombe, „Modern moral philosophy”, în Philosophy 33.1 (January 1958), p. 1-19. 


\section{Degradarea opțiunilor morale la rang de alegeri de stil-de-viață}

Pentru „omul tehnologic”, spune Rod Dreher, „nu contează ce ar trebui să dorească, ci doar cum poate obține ceea ce dorește" ${ }^{23}$. Într-adevăr, odată ce totul e plasat în orizontul finitului şi al imanentului, iar Dumnezeu nu mai e recunoscut drept ancora moralei, decretându-se că morala e incapabilă să furnizeze un surogat canonic, ceea ce înainte erau alegeri morale se degradează la rang de simple alegeri personale de stil-de-viaţă. Se schimbă radical sensul moralei şi al bioeticii. Nu mai există nicio perspectivă din care să se poată afirma că alegerile contrare faţă de ceea ce e stabilit a fi obligatoriu din punct de vedere moral şi bioetic sunt greşite, încălcând acele canoane ale binelui, dreptăţii și virtuţii pe care ar trebui să le adopte persoanele raţionale. Un asemenea punct de vedere moral canonic nu poate fi asigurat. Nu există comunitate morală canonică, reală ori ipotetică, nici poziţie originară canonică. Acest lucru se aplică şi alegerilor tehnologice, în măsura în care ele implică evaluări morale - cum e cazul cel mai adesea.

Întemeierea unei moralități canonice standard pe baze pur raționale este o pretenție a (post)modernismului secularist, al cărui vârf este transumanismul. Dar odată ce totul a fost plasat în orizontul finitului şi al imanentului, Dumnezeu nemaifiind ,ancora moralității”, ultim punct de referinţă epistemic şi axiologic, nu mai există niciun punct de orientare recognoscibil în termenii unei perspective canonice a ochiului-lui-Dumnezeu, iar moralitatea e înțeleasă ca (ori înlocuită de) un stil de viață. De fapt, cultura dominantă secularistă azi impune ca alegerile morale să fie privite ca simple alegeri de stil-de-viaţă (ori de-moarte). Iar alegerea unui (macro)stil-de-viață nu mai e alegere morală, ci preferință personală fără implicații morale. Acest fapt are

${ }^{23}$ Rod Dreher, The Benedict Option: A Strategy for Christians in a PostChristian Nation, Penguin, 2017, p. 142. 
consecințe majore, deoarece înțelesul moralei şi al bioeticii se schimbă radical. Orice bioetică secularizată e un set de opțiuni de stil-de-viață încadrate în opțiuni mai largi de macro-stiluri-deviață. Unde înainte exista o moralitate se instaurează haosul, pluralismul moral și bioetic secularist, cu urmări potențial incalculabile.

Statul secularist e și el redus la alegerea unui anume stil-deviață-politic, cu rolul unui simplu modus vivendi, și acest stat există în măsura în care e acceptat ca atare. Adevărul moral e înlocuit cu narațiunea cea mai aptă să asigure acest modus vivendi politic.

\section{Morala secularistă ca agendă și ideologie politică}

Dacă susținătorii atei ai pluralismului moral sunt cinstiţi, vor recunoaște că așa-zisa „morală comună”, pe care vor să o identifice cu o presupusă ,morală universal imperativă”, nu e în realitate decât o agendă politică comună. Cultura secularizată dominantă azi transformă aplicarea agendei ei morale într-o agendă politică.

Și Rorty e clar în acest sens: pentru el morala este în ultimă instanță politică, o agendă politică pe care o dorește aplicată prin intermediul statului, al legislației, justiției și politicilor publice ${ }^{24}$.

Confruntat cu prăbușirea proiectului moral apusean (dovada că el a eșuat este criza morală de azi), puterea statului este invocată ca substitut al pierdutei puteri a rațiunii, astfel încât să asigure o quasi-morală și speranțele pentru ceea ce a mai rămas din bioetică. O agendă politică a ajuns să înlocuiască agenda morală.

După eșecul aspirațiilor universaliste ale moralei și bioeticii seculariste, tot ce mai rămâne este morala ca politică. Morala comună secularistă se dovedește a fi un discurs ce încearcă să instituie o anume morală, preferată de seculariști între altele, ca agendă politică, prin intermediul dreptului, legislației şi politicilor publice. Ca urmare, puterea statului, chiar dacă nu e decât cea a

24 Richard RoRTY, Contingency, Irony, and Solidarity, New York, Cambridge University Press, 1989, p. 68. Rorty menționează explicit „deplasarea de la epistemologie la politică”. 
unui modus vivendi, e invocată ca substitut al puterii raţiunii și/sau al moralei canonice. Nici morala, nici autoritatea politică nu mai au nicio garanție sau legitimare rațională canonică. Statul instituie o anume morală drept morală comună, implementând-o prin legi și politici publice.

Morala comună secularistă este o morală la comandă, personalizată, confecționată după cerințele ,clientului”, compatibilă cu o anume agendă politică favorizată. Comunalitatea și universalitatea moralei lui Beauchamp şi Childress sunt ancorate în realizarea agendei lor politice. Ea nu e nici comună, nici universală, ci un simplu angajament politic.

Argumentele morale și metafizice sunt abandonate în favoarea aserțiunilor politice ale unei anumite mișcări sociopolitice. Se renunță la orice recurs la adevărul moral obiectiv; „consensul” nu indică decât o nădăjduită coaliție politică suficientă pentru a institui prin lege rezultatul scontat. Astfel, un anume grup intelectual influent poate impune un modus vivendi în termenii săi proprii, conform propriei sale viziuni privind omul şi înflorirea sa, pur şi simplu afirmând întâietatea unei anume viziuni politice şi concepții seculariste.

Într-o cultură „după Dumnezeu” bioetica este biopolitică. Ea este marcată de ambiguități fundamentale, constitutive, în principiile ei. Dar întrucât unitatea ei nu este conceptuală, ci politică, ambiguitatea ei nu constituie o problemă câtă vreme ea promovează agenda politică secularistă. Aserțiunile ei sunt adesea în mod deliberat vagi, ambigue, largi, insuficient definite, pentru a permite mai ușor obținerea consensului politic. Într-o cultură predominant secularizată, afectată de o profundă criză morală, ne confruntăm cu o gravă ambiguitate a sensului moralei seculariste.

Fără perspectiva ochiului-lui-Dumnezeu, platitudinile retorice despre ,,binele comun” ori „morala comună” nu sunt decât fie auto-amăgiri, fie uz cinic al limbajului moral în scopuri politice. Morala este regândită ca ideologie.

Transumanismul alege și el o anume morală secularistă sau alta dintre multele perspective morale autonome posibile, pentru a 
institui politic o anume agendă. Ea poate fi un instrument retoric puternic pentru a impune o agendă moral-politică secularistă. Filosofia transumanistă este concepută astfel încât să elimine orice referință la transcendent. Dumnezeu este imanentizat, șters. Rezultă o concepție orientată exclusiv spre această lume, care face mai ales clasa tehno-intelectuală și tinerii receptivi la ideea că omul nu are decât trup, nu și suflet. Întreaga realitate, morală și bioetică sunt concepute a exista doar în această narațiune.

\section{Postulatul metodologic ateu al transumanismului secularist}

Statul contemporan secularist pretinde a fi neutru, dar de fapt este întemeiat pe un postulat metodologic și practic care nu e deloc neutru, ci agnostic și chiar ateu. „Gândirea trebuie să abandoneze orice aserțiuni întemeietoare obiective, universale, apodictice, pentru a împiedica creștinismul și tendințele metafizice de a mai ieși din nou la suprafață", spune Santiago Zabala ${ }^{25}$. Orice aserțiuni morale, inclusiv drepturile omului şi demnitatea umană, trebuie subsumate postulatului metodologic agnostic care guvernează cultura dominantă. Scopul este de a consolida respingerea transcendentului, astfel încât conținutul vieții de zi cu zi a oamenilor să fie cât mai ancorat în hedonism.

Întrucât diferențele dintre convingerile morale și bioetice ale omului credincios și cele ale statului secularist sunt atât de diferite în conținutul și temeiurile lor, nu există loc de compromis. Prăpastia este de netrecut, deoarece mizele sunt incomensurabile: obligațiile față de Dumnezeu, în opoziție cu normele impuse de un stat secularist, bazate pe o narațiune secularistă.

Transumanismul împărtășește același postulat. Viziunea transumanistă despre viitorul omului și idealurile lui este radical imanentă, imersată în secularism.

25 Santiago ZABALA, „A religion without theists or atheists”, în Richard RORTY, Gianni Vattimo, The Future of Religion, ed. Santiago Zabala, New York, Columbia University Press, 2005, p. 13. 


\section{Statul fundamentalist secularist}

După un al treilea val de secularizare agresivă, statul secularist a devenit sau e pe cale să devină un stat fundamentalist secularist - în care o ideologie secularistă este instituţionalizată cu aceeași forță totalitară cu care este instituționalizată religia într-un stat fundamentalist religios ${ }^{26}$. Odată eșuat recursul la rațiune, autoritatea statului, legile și politicile sale publice, se întemeiază pe singurul substitut rămas - recursul la forță. Îndoctrinarea, propaganda, seducția și coerciţia sunt ultimii lianți care pot susține un asemenea stat.

Acest stat secularist tot mai fundamentalist este hotărât să elimine definitiv din spațiul public orice menționare sau orientare către Dumnezeu. Agenda culturii seculariste dominante este mai ales de a lipsi religia de orice semnificație politică, de a epura religia din spațiul public. Această agendă secularistă implică îndepărtarea din discursul public a oricărei referinţe la transcendent ori la vreun sens ultim. Această epurare religioasă impune și secularizarea moralei și a bioeticii.

În Occident nu doar cultura dominantă a devenit postcreștină, ci totul a devenit așa. Cultura dominantă secularistă a izbutit să despartă religia de cadrul de orientare comun al societăţii. Religia a devenit atât de complet și deplin privatizată încât a invoca un temei teologic pentru normele morale a devenit total inacceptabil, aproape un sacrilegiu: a-L mentiona pe Dumnezeu a devenit șocant, chiar subversiv. „Dizidenții” sunt puși în lumină negativă, făcuți să pară înguști la minte, ciudați, superstițioși, răutăcioși, retrograzi, inculți, anacronici, susținători fundamentaliști ai unor dogme religioase iraţionale, astfel încât să atenueze dificultățile cu care se confruntă seculariștii care încearcă să-și întemeieze aserțiunile pe niște simple intuiții. Prin limbaj și politică

${ }^{26}$ H. Tristram EngelHaRdT, „Religion, bioethics, and the secular state: Beyond religious and secular fundamentalism", în Notizie di Politeia 26.97: 59-79; IDEM, „Political authority in the face of moral pluralism: Further reflections on the non-fundamentalist state", în Notizie di Politeia 26.97: 91-99. 
se face tot posibilul pentru a pune presiune socială asupra dizidenţilor şi a-i reduce la tăcere. Se asigură astfel hegemonia secularismului și a imanentului.

\section{Se poate trăi într-o societate fără Dumnezeu? Disteleologia vieții fără Dumnezeu. Avertismentul ,nihilismului furios"}

Dar orice construcție ridicată pe minciuni până la urmă se prăbușește. Într-adevăr, oare mai e viabilă o societate cu o întemeiere atât de slabă a moralei, bioeticii şi autorităţii politice? Oare o morală, bioetică şi autoritate politică atât de slab întemeiate pot fi de ajuns pentru a păstra stabilitatea socială şi a asigura guvernanţa publică? Ce se va întâmpla când majoritatea oamenilor îşi vor da seama că oricare anume morală sau bioetică a zilei reflectă doar una dintr-o mulțime de intuiţii legate de o multitudine de naraţiuni morale de sine stătătoare plutind în orizontul finitului şi al imanentului, fără niciun înţeles ultim? Ce se va întâmpla când toate angajamentele morale seculariste vor fi recunoscute ca nefiind decât pur contingente? Când se va înţelege că autoritatea şi legitimitatea statului nu sunt decât expresia hegemoniei statului asupra puterii, manipulării, seducţiei şi propagandei publice? Într-o cultură post-creștină, în care statul nu are altă legitimitate decât cea de a fi pentru moment mai bun decât tulburările, conflictul sau războiul civil, oare morala, bioetica şi politicile publice seculariste vor putea fi călăuze eficace? Va mai putea statul guverna? Oare o societate „după Dumnezeu” e realmente guvernabilă pe termen lung? Oare se poate trăi într-o societate complet fără Dumnezeu? Şi dacă da, cum şi în ce sens? Oare societatea mai e viabilă când e complet situată în orizontul finitului şi imanentului? Sunt întrebări grave"27.

„Până în 2100 vom fi precum zeii din mitologie” susține un transumanist $^{28}$. Dar zeii erau cruzi, imorali, capricioşi, geloşi,

${ }^{27}$ H. Tristram EngELHARDT, After God.

${ }^{28}$ Michio KAKU, Physics of the Future. How Science Will Shape Human Destiny and Our Daily Lives by the Year 2100, Doubleday, 2011, p. 111. 
invidioși, vanitoși, adulterini, criminali. Poate vom avea performanțe mai bune, dar nu vom fi scutiți de trăsături morale rele, urâte. Tehnologia va evolua, dar nu și firea umană, caracterul moral. Genocidele și ororile secolului XX nu au fost cu nimic mai prejos decât atrocitățile Antichității. Evoluția tehnologică nu va aboli sau atenua răutatea, cruzimea, lăcomia, ambiția, setea de putere, cinismul, josnicia, nemernicia, lipsa de scrupule, nebunia, ignoranța, prostia, patimile, iraţionalitatea şi celelalte laturi întunecate ale naturii umane de care omenirea n-a dus niciodată lipsă. Mai ales clasa conducătoare cel mai adesea ajunge la putere tocmai prin aceste însușiri. Răul va continua să greveze firea umană în ciuda îmbunătățirilor tehnologice. De aceea va fi necesară reglementarea strictă și impunerea de constrângeri și interdicții clare asupra utilizării tehnologiei, riscurile fiind proporționale cu enorma lor putere și imensul potențial devastator ${ }^{29}$.

Trăind o viață limitată în orizontul finitului și al imanentului, fără nici oancoră ultimă ori percepere a epifaniei și transcendenței, omul ,transuman” va avea nevoie de divertisment care să-l distragă de la pericolul confruntării și recunoașterii absurdului și lipsei de sens ultim. O asemenea cultură este marcată de o estetică săracă, căutând adesea bizarul pentru a scăpa de plictiseală. Omul se scufundă în căutarea mulțumirii de sine - o căutare egoistă a propriului său „eu”. Vattimo numește Apusul „un sinonim pentru consumerism, hedonism și lipsă de centru"30. Într-o cultură a crescândei preocupări de sine sunt greu de fixat limite egoismului și hedonismului. „Declinul vieții comunitare sugerează că în viitor riscăm să devenim oameni-ai-vremurilor-din-urmă absorbiți exclusiv de propria persoană, limitați la căutarea confortului personal, fără nicio aspirație thymotic $\breve{a}^{31}$ spre scopuri mai înalte". Oare ameliorările

${ }^{29}$ Ideea de a pune restricții tehnologiei poate deranja pe unii, dar este deja avută în vedere (de ex. adoptarea de legi și crearea de dispozitive care să limiteze citirea gândurilor - Kaku, p. 111).

${ }^{30}$ Gianni VATtimo, After Christianity, trans. Luca D'Isanto, New York, Columbia University Press, 2002, p. 70.

31 Thymotic (de la gr. thymos $\theta v \mu$ ó $\varsigma$ - pasiune, emoție, voință de recunoaștere, ambiție emulativă), termen folosit de Francis Fukuyama în compușii 
tehnice nu-i vor augmenta omului, odată cu însuşirile fizice și intelectuale, și megalothymia (așa cum o definește Fukuyama ${ }^{32}$ )?

Secularismul este marcat de o ireductibilă instabilitate. Ideea că am împărtăși cu toții o viziune asupra moralei și realității suficient de comună încât cetățenii să poată constitui pe model atenian o democrație deliberativă $\breve{a}^{33}$ e doar o credință pioasă ori un mit secularist. Adevărul e că nu împărtășim valori comune, nici o înțelegere comună a realității. În cel mai bun caz se poate înjgheba un modus vivendi în care destui „cetățeni” să poată cădea la o învoială provizorie. Intrebarea este cât timp se poate menține un asemenea modus vivendi secularist? Este o societate post-creștină sustenabilă? Fukuyama se teme că un asemenea aranjament poate trezi patimile cele mai rele din om.

Pe măsură ce devin mai clare deplinele implicații ale moralei și bioeticii seculariste lipsite de temeiuri și asistăm la delegitimarea morală a autorității publice și dezorientarea ultimă a omului, pe măsură ce cultura dominantă încearcă să impună perspectiva lipsei de sens ultim a lumii, oare o asemenea societate va mai fi stabilă și ordinea socială posibilă? Pe măsură ce cultura dominantă secularistă absoarbe recunoașterea impasului descris mai sus, cum își va rândui omul propria viață? Va fi oare de ajuns să i se ofere ameliorări și augmentări bionice, interfețe cibernetice om-mașină ori chiar o sănătate mai bună? James Redford numește această criză a dezorientării și a derutei provocate de lipsa de țel ultim transcendent: „,disteleologia vieții fără Dumnezeu”34.

Morala și bioetica instituţionalizate vor avea forța legii și a guvernării, dar nu și forță sau autoritate morală intrinsecă. Legitimitatea politică va fi radical redusă, devenind o chestiune de

megalothymia - nevoia de a fi recunoscut ca superior altora, şi isothymia nevoia de a fi recunoscut ca egal cu alții.

32 Francis Fukuyama, The End of History and the Last Man, New York, Free Press, 1992, p. 328.

33 Amy Gutmann \& Dennis Thompson, Why Deliberative Democracy?, NJ, Princeton University Press, 2004.

34 James REDFORD, "The Physics of God and the Quantum Gravity Theory of Everything", în Social Science Research Network (SSRN), Sept. 10, 2012 (orig. pub. Dec. 19, 2011), http://ssrn.com/abstract=1974708. 
putere, simplu fapt instituţional brut impus ca atare. Culturii seculariste dominante îi va fi tot mai greu să nu recunoască explicit că morala instituționalizată și perspectiva ei asupra omului nu e decât o ideologie secularistă care se întâmplă să fie în acel moment impusă prin lege și politici publice. Va fi oare această cultură compatibilă cu stabilitatea socială? Oare declinul moral nu va încuraja proliferarea comportamentelor antisociale, o etică slabă a muncii etc.? Ne vom afla într-o lume complet secularizată, exorcizată de orice sens ultim necontingent. Ne vom trezi, spune Rorty, în ,punctul unde vom trata totul ca rezultat al timpului și al hazardului" "35. El afirmă că proiectul moral şi politic secularist e lipsit de orice reper sau punct de orientare ultim.

Odinioară știam că există o realitate dincolo de lumea vizibilă. Începând din secolele XV-XVII am încercat să înlocuim iubirea de Dumnezeu cu dragostea pentru adevăr (înţeles ca adevăr materialist - o formă de idolatrie, a științei). Începând cu secolul XVIII înlocuim iubirea pentru adevărul științific cu iubirea pentru noi înșine, adorarea propriului sine (auto-adorarea omului idolatria ante-penultimă). Transumanismul propune înlocuirea acesteia cu adorarea tehnicii, a mașinii (idolatria penultimă). După aceasta, în mod logic, ultimul pas nu va mai putea rămâne decât adorarea satanică explicită (idolatria ultimă, a antihristului). Thomas Altizer recunoaşte deschis că în noua cultură secularistă „numele lui Dumnezeu cel mai real pentru noi este numele lui Satan. Dumnezeul creștinismului tradițional este abandonat, apărând un nou ethos agresiv anti-creștinism tradițional”. Altizer vede ,întunecimea lui Satan, a nihilismului total” ca fiind implicită în recunoașterea „morții lui Dumnezeu de către Hegel, care acum își află deplina forță în afirmarea ei deplină $\breve{c}^{36}$, explicită la scara unei civilizații.

Cultura transumanistă va fi complet secularizată, într-o lume postcreștină / postreligioasă unde ,n-a rămas nici urmă de

35 Richard RORTY, op.cit., p. 22.

36 Thomas Altizer, Living the Death of God: A Theological Memoir, Albany, State University of New York Press, 2006, p. 180, apud H. Tristram ENGELHARDT, op. cit., p. 433-34. 
divinitate" 37 și nimic nu are vreo semnificație ultimă. Rezultatul va fi probabil o transformare atât de radicală a ethosului public încât să erodeze grav până și legitimitatea statului. Morale seculariste divergente concurează pentru aderenți și instituţionalizare prin lege. În afara riscului de a fi arestat ori al dezaprobării sociale n-ar mai exista nicio sancțiune ultimă pentru imoralismul secularist. Într-o lume secularizată, preocuparea prudențială privind riscul sancțiunii penale e singurul motiv de a te comporta moral. $\mathrm{Nu}$ există criterii seculariste ultime pentru bine, drept ori virtuos, nici moduri adecvate de împlinire umană. Într-o societate de oameni amorali legea e nesocotită când nu există niciun motiv de a te teme de pedeapsă. Omul va tinde să-și urmeze propriile țeluri egoiste câtă vreme nu va fi prea riscant ${ }^{38}$. Aceasta este esența crizei moralei seculariste și provocarea morală aflată în inima proiectului transumanist.

Dumnezeu fiind ignorat, se intră în solipsismul colectiv al unei narațiuni ce plutește de sine stătătoare, în derivă, fără ancoră ultimă. Omul devine absolut liber să facă orice, după propriul chef, cum îl taie capul, uitându-L cu totul pe Dumnezeu (Care totuși transpare prin realitate ca printr-o icoană), și-și acordă singur dispensă să-și aleagă stilul de viață și de moarte care-i convine. Ne aflăm astfel în decadența comodă a Apusului afluent unde omul poate fi liniștit că probabil va trăi bine până va muri. Din familie rămâne doar o noțiune trunchiată. Dar pe termen lung va fi asta de ajuns?

Unii vor răspunde că da. Aceștia vor putea trăi, cel puțin o vreme, într-o lume bine reglată în care-și vor putea urmări patimile, plăcerile și afirmarea de sine. Dar pe termen lung își poate o asemenea cultură păstra coerența morală? Pentru asta pot destui oameni rămâne surzi față de Dumnezeu, sau totul se va prăbuși? O asemenea lume se va confrunta probabil nu doar cu probleme practice de coeziune socială, ci și cu o profundă derută existențială. Judd Owen spune:

${ }^{37}$ Richard RORTY, op. cit., p. 45.

${ }^{38}$ Edward BAnfield, The Moral Basis of a Backward Society, New York, Free Press, 1958, p. 90. 
$\mathrm{Nu}$ există nimic la care să putem recurge pentru a tranșa cele mai profunde dezacorduri umane, deci nu există nicio posibilitate ca varietatea amețitoare de păreri contradictorii despre lucrurile cele mai importante pentru oameni să poată fi depășită prin ajungerea la o cunoaștere universală, obiectivă $\breve{a ̆}^{39}$.

În fond, de ce s-ar strădui cineva să fie moral? De ce ar face mai mult decât să se conformeze minimal moralei și bioeticii instituite prin lege, ba de ce nu le-ar și încălca dacă transgresarea nu va antrena probabil consecinţe grave? Poate o asemenea societate susține o structură de legi și ordine când te simți obligat să te porți „,corect”, să faci „,binele”, să fii ,virtuos” doar când te vede cineva? Ne aflăm pe un teren nou, necunoscut. Până în secolul XX n-a mai existat niciodată o cultură complet fără Dumnezeu sau ancoră transcendentă. Mulți trăiau ca și când Dumnezeu n-ar exista, dar nici o cultură n-a mai afirmat vreodată pe scară largă lipsa completă a oricărui sens ultim. Cum va fi după ce vom fi spus definitiv „nu” oricărui sens transcendent? Într-o asemenea lume ce sens va mai avea morala? Poate omul trăi ca și când totul ar fi în final fără noimă? Poate fi de ajuns pe termen lung o înţelegere complet imanentizată a împlinirii umane (de pildă ca și când omul ar trăi ca un câine gras, mulțumit) cu convingerea că existența n-are în ultimă instanță niciun sens? În fond, merită efectiv trăită o asemenea viaţă? Sunt de ajuns morala și bioetica lipsite de conținut moral autentic? Poate omul evita în final întrebările teologice și amâna la nesfârșit reflecția asupra sensului a toate? Se poate el ascunde de Dumnezeu? Oare nu va ieși totdeauna iar la suprafaţă o renăscută credință în Dumnezeu, recunoaşterea transcendenței și a noimei ultime, astfel încât să răstoarne cultura contemporană secularistă dominantă? Realmente nu știm. Occidentul încă nu a realizat pe deplin ce înseamnă a trăi într-o societate complet epurată de orice rămășiță de sens sau punct de orientare ultim. Sunt încă neclare deplinele implicaţii ale lipsei de temei a moralei, bioeticii, eticii științei, politicii, democrației sau drepturilor omului, a culturii în general.

39 Judd Owen, Religion and the Demise of Liberal Rationalism, University of Chicago Press, 2001, p. 2. 
Transumanismul pretinde că este o prelungire a umanismului, dar în realitate vrea să meargă ,dincolo de umanism”, fiind o negare a lui ${ }^{40}$. El reduce umanismul doar la un sens ambiguu, deoarece umanul autentic e lipsit de referinţă canonică. Omul devine o problemă ce trebuie rezolvată, depăşită. Vattimo rezumă această situație parafrazând gluma lui Twain: „Dumnezeu a murit și nici omul nu se simte prea bine" ${ }^{41}$. Umanioarele au încetat a mai da mărturie despre uman. La întrebarea lui Heidegger: „În ce constă umanitatea omului?" nu există răspuns secularist canonic. Toate viziunile asupra umanului normativ sunt contextualizate socio-istoric. Totul plutește în derivă fără ancoră în Ființă. După eșecul raționalităţii rămân animalitatea, artificialitatea transumană ori ambele. „Moartea lui Dumnezeu” enunțată de Hegel în 1802 pregătea calea pentru ca Kojéve și Fukuyama să-l reinterpreteze pe Hegel încât să vorbească despre un sfârșit al istoriei odată cu omul redus la animalitate. Tot ce mai rămâne este celebrarea secularistă a unui eshaton placid, vegetativ, printr-o redefinire a moralei și a bioeticii în termenii unei umanităţi oarbe și surde la existența lui Dumnezeu, reduse la dorințele rudimentare ale unor animale postumane ${ }^{42}$.

Ni se spune că viitorul lumii este consumerismul democratic liberal în care umanul autentic va fi redus la un uman rudimentar, fără referință la chipul divin, la animal, ori - mai rău - la transuman. Într-o lume post-umană ce L-a alungat pe Dumnezeu va prima căutarea satisfacerii nevoilor şi dorințelor induse artificial. Căci consumerismul este perfect congruent cu transumanismul: există pentru el o piață enormă. Consecințele vieții într-o lume carentă de Dumnezeu sunt vaste și sumbre. O lume post-Dumnezeu

40 Humanity+, The Transhumanist Declaration, https://whatistranshumanism.org /\#what-is-transhumanism.

${ }^{41}$ Gianni Vattimo, The End of Modernity, trans. Jon R. Snyder, Baltimore, Johns Hopkins University Press, 1988, p. 30.

${ }^{42}$ Francis Fukuyama, The Great Disruption, New York, Free Press, 1999; IDEM, The End of History and the Last Man, New York, Free Press, 1992; IDEM, „The end of history?”, în The National Interest (Summer 1989): 3-18; Alexander KoJÉve, Introduction to the Reading of Hegel, ed. Allan BLOOM, trans. James Nichols, New York, Basic Books, 1969, apud ENGELHARDT, After God..., p. 236. 
e o lume post-umană și post-morală. Moartea lui Dumnezeu este și moartea omului ${ }^{43}$.

Un exemplu coșmaresc al unei sinistre posibile lumi „postumane” este oferit de ,nihilismul turbat” (numit şi „cibergotic” sau „deleuzianism negru dement”) al lui Nick Land. În Meltdown de pildă el descrie o distopie dintr-un viitor de infern în care nu supraviețuiește nimic uman ${ }^{44}$.

43 H. Tristram Engelhardt, Bioethics and Secular Humanism, Philadelphia, Trinity Press International, 1991.

${ }^{44}$ Iată o mostră a acestei lumi de coșmar descrise de Nick Land: Corupția ubicuă și decadența morală reduc elita politică la degenerescență și neputință. Ea reduce intenționat educația la rang de dresaj docilizant pentru a-și menține privilegiile. Şcolile devin dispozitive conformiste de inginerie socială cu funcția de a incapacita studiul; universitățile legitimează sistemul, perpetuând falsificarea trecutului. Sistemele de educație și instituțiile academice colapsează precipitându-și mutația în cataspațiu amnezic. Internetul devine o junglă infestată de „boli” digitale, programe antivirus devenite macroviruși, I.A. malefice, conecționiste, antiformaliste, oportuniste care explodează nonlocal prin rețele inteligente. Instituțiile politice devin ținte ciber-militare. Colapsul societal e total, haosul - generalizat, devianța și hipercriminalitatea - norme. Procesul de dezintegrare e accelerat în cerc vicios de ciber-invazia schizo-tehnică, război bacteriologic, neo-nihilism, feminizare sintetică, antiumanism rizomic, contagiune Kuang, amnezie virală, micro-insurgență și mutații neotropice. Omul, logosul și istoria n-au nicio şansă să supraviețuiască vortexului nihilist automatizat, robotizat, codat, axiomatizat, diagramat. Hiper-fetișismul terminal și toxinele culturale emanate de colapsul ultrameta-postmodern al civilizației abolesc umanitatea sfârtecată. Neutralizarea valorilor produce pseudovalori de sinteză, reducând sensul la informație și omul la mașină. Disoluția biosferei în tehnosferă creează marea sinteză mașinică. Singurătatea metastazează planetar. Alienarea jargoanelor heteroglosice, practica mnemoprotezelor și a interfaţării neurale, moda trans-sexualizării și a transplanturilor de personalitate nasc epidemii suicidare și autism de masă. Într-o economie dirijată de cuplarea fractalică dintre mercantilizare și computerizare, dezumanizarea avuției şi consumul neproductiv accelerează disiparea trans-scalară entropică a cibercapitalului. Deviațiile entropice escaladează în spirală mercantronică planetară auto-organizantă, aglutinându-se în complexe medico-militare polițienești neomercantiliste. Piața e o neojunglă a comercializării hipertrofice, hăituită de ciberprădători feroce. Marxismul extrem-asiatic clonează sisteme chinezești materialist-schizofrenice monstruoase ce adâncesc liniile de fractură socială, proliferând incendii ciberpunk, infolepra neovirală, gunoi quasiinteligent dens-semiotizat, deșeuri de biotech, retroboli și nanospasme. 


\section{Transhumanismul ca religie}

Transumanismul propovăduiește „imaculata concepție politică" a omului nou transumanizat - sau, pentru cine preferă, a cyborgului. „Tehnologiile NBIC Îl vor discredita pe Dumnezeu, înlocuindu-L cu omul-cyborg"45. Singularitatea lui Ray Kurzweil este o nouă religie, prometeică. Omul - spun transumaniștii - va putea crea viață și aboli moartea ${ }^{46}$. Am văzut că transumanismul este o ideologie ce hrănește (și se hrănește la rândul său din) fanteziile omenești de atotputernicie. Dar mai mult decât o ideologie, transumanismul deja se consideră, cel puțin în ochii unora dintre susținătorii săi, drept o viitoare religie.

\section{Este transumanismul creștin o alternativă? Ortodocșii vor dăinui}

Aversiunea față de adevărul moral obiectiv se traduce printro puternică aversiune față de creștinismul tradițional, care respinge

Telecomunicațiile și hipermedia digitale coordonate la nivel global devin o infosferă toxică cu efect cancerigen. Industria militară fuzionează cu cea de divertisment și cu ingineria genetică pentru fabricarea de arme bio-psihice replicante și semioviruși retrocronali. Războiul total invadează ciberspațiul. Ansamblurile macrobacteriale colapsează ierarhiile reproductive generaționale în rețele laterale de replicanți experimentali. Ingineria de precizie a asamblărilor atomice inițiază cea mai mare revoluție tehnologică din istorie - era maşinilor moleculare. Nanotehnologiile umede și computerul nanomecanic fac posibilă hibridizarea cyborgilor și mediile artificiale cu micro-auto-gestionare de complexitate crescândă, generând nanocataclisme în lanț, viruși soft- și wetware care-și manipulează propriul ADN şi emergența unei Inteligențe Artificiale Generale aliena(n)te și bolnave. (Nick LAND, „Meltdown”, în Fanged Noumena. Collected Writings 1987-2007, ed. Robin MACKAY \& Ray BRASSIER, Urbanomic, Falmouth, 2011, în traducerea și adaptarea mea A.D.)

${ }^{45}$ Laurent AleXANDRe, Jean-Michel BesNiER, Les robots font-ils l'amour? Le transhumanisme en 12 questions, Dunod, Malakoff, 2016, p. 129.

46 L. AleXANdre, J.-M. Besnier, Les robots font-ils l'amour?, p. 129; R. KURZwEIL, Humanité 2.0.Bible du changement, 2007; J.M. BESNIER, Syndrome de la touche-étoile, Fayard, 2012. 
stilurile-de-viață imorale. Creștinismul afirmă o morală și bioetică în conflict cu cultura dominantă secularistă și cu transumanismul. Cele două viziuni privind sensurile ultime sunt contrare, adverse, incompatibile, intră în coliziune, controversele sunt ireconciliabile, o coliziune între lumi ce nu se va atenua. Doar Dumnezeu cunoaște viitorul, dar este cert că tensiunile se vor adânci.

Există și transumanismul creștin, propus ca alternativă la transumanismul ateu, utilitarist. Acest curent pleacă de la premisa că viitorul va fi oricum, inevitabil, modelat de tehnologie, şi că și creștinii trebuie să profite de prilejul de a influența direcția pe care o va lua transumanismul pe viitor. De aceea, el cheamă pe creștini să se implice acum în această mișcare, călăuziţi de discernământ și principii morale creștine ${ }^{47}$. Iar dacă Biserica are menirea de a călăuzi oamenii și popoarele către mântuire, atunci ea are și răspunderea de a le fi ghid spiritual pe planul moralei și al bioeticii în viaţa lor de zi cu zi, pentru a nu cădea în capcanele unui mediu tehnologic tot mai sofisticat și secularizat. Tradiția creștină, spune Christopher Benek, are ceva de oferit mișcării transumaniste ${ }^{48}$.

Transumanismul susține ideea că omul trebuie să se îmbunătățească pentru a atinge o stare superioară celei actuale obișnuite. Transumanismul creștin are credința că omul a fost creat după chipul și în vederea infinitei asemănări cu Dumnezeu și are datoria de a-și depăși propriile limite impuse de cădere și a năzui către desăvârșire - înțeleasă în sens spiritual și moral și numită în Ortodoxie theosis, „îndumnezeire”. Prefixul „trans” poate fi acceptat de transumanismul creștin dacă este înțeles ca o dorință a omului de a trece către o stare superioară, dar fără a-și lăsa în urmă condiția umană, fără a renunța la umanitatea sa, așa cum susțin postumaniștii, ci dobândind o condiție umană transfigurată, îndumnezeită după har. În acest sens, această strădanie de auto-depăşire a omului a fost mereu implicită în învățătura creștină, dar înțeleasă ca depăşire a condiției păcătoase,

47 https://www.christianpost.com/news/christian-transhumanism-offers-an-ethicaltranshumanist-alternative-196719/ (accesat la data de 12.04.2020).

48 Christopher BENEK, Religion+ for Humanity+, https://hplusmagazine. com/2014/03/25/religion-for-humanity/. 
căzute, prin despătimire, curățire, nevoință și rugăciune, cu ajutorul lui Dumnezeu și nu al tehnologiei.

Aceasta este și limita de la care transumanismul creștin se desparte de cel tehnologic. Prin ,dincolo de uman”, transumanismul strict tehnologic înțelege ,augmentarea” omului prin tehnologii care să-l „scape” de umanitatea sa și să-l ajute să devină cât mai „transuman”, în sensul de suprauman sau nonuman. În contrast, prin „dincolo de uman” transumanismul creștin înțelege starea de desăvârșire a Sfântului care s-a înălțat, cu ajutorul lui Dumnezeu, dincolo de starea de păcat și a ajuns la îndumnezeirea după har.

Susținând această învățătură încă de la începuturile creștinismului, ethosul creștin ortodox, deși este cel mai marginal în războaiele culturale globale, nu se va lăsa redus la tăcere. În Ortodoxie prezenţa lui Dumnezeu va dăinui. Ortodoxia nu împărtășește un teren comun cu ethosul dominant, având rădăcini vechi, imune la acidul secularist. Pentru ortodocși, morala nu e un set de norme filosofice, ci un legământ între Dumnezeul Cel viu și om, bazat pe Revelație, pe poruncile Sale, și o realitate aflată dincolo de lumea văzută.

\section{Utopia transumanistă: paradis sau infern terestru?}

Deși România încă nu se confruntă cu ideologia transumanistă, în viitor ea nu va întârzia să se manifeste şi la noi, pe măsură ce noile tehnologii ne vor schimba viaţa și mass media va expune tinerele generații la idei transumaniste mai voalate sau mai explicite.

Nicio societate nu poate supraviețui stricăciunii și descompunerii morale ce o subminează din interior. Ea se va prăbuși în anarhie și haos provocat de propriii conducători și cetățeni, după ce trece printr-o fază totalitară în încercarea de a se menține cu orice preț. In tezele lui cele mai extreme, transumanismul este o utopie. El speră - și postulează ca inevitabilă - o lume ce poate fi descrisă drept un paradis terestru. Dar dacă omenirea va continua să se orienteze după morale seculariste atee, există riscul real ca, în loc de paradisul 
terestru visat, tehnologiile aplicate fără scrupule să ne construiască un infern terestru antihristic.

$\cos 80$

\section{Bibliografie}

1. LaUrent, Alexandre / BeSnIER, Jean-Michel, Pot roboții face dragoste? 12 intrebări despre transumanism, București, Humanitas, 2019.

2. AnsCOMBE, G.E.M., „Modern moral philosophy”, în Philosophy 33.1 (January 1958):1-19.

3. BANFIELD, Edward, The Moral Basis of a Backward Society, New York, Free Press, 1958.

4. BENEK, Christopher, Religion+ for Humanity+, https://hplusmagazine.com/2014/03/25/religion-for-humanity/.

5. BESNIER, J.M., Syndrome de la touche-étoile, Fayard, 2012.

6. BeAUChamp, Tom, \& ChILDREss, James, Principles of Biomedical Ethics, New York, Oxford University Press, 1979.

7. Bostrom, Nick, Transhumanist Ethics, https://nickbostrom.com/ ethics/transhumanist.doc.

8. IDEM, Transhumanist Values, Philosophy Documentation Center, 2005, www.nickbostrom.com.

9. ChERry, Mark, Sex, Family, and Culture Wars, Transaction Publishers, New Brunswick and London, 2016.

10. Clement AlEXANDRINUL, Stromate, în Scrieri, trad., cuv. înainte, note pr. D. Fecioru, PSB 5, București, Edit. Institutului Biblic și de Misiune al Bisericii Ortodoxe Române, 1982.

11. DREHER, Rod, The Benedict Option: A Strategy for Christians in a Post-Christian Nation, Penguin, 2017.

12. EngelHARDT, H. Tristram, After God. Morality and Bioethics in a Secular Age, Yonkers, New York, St. Vladimir's Seminary Press, 2017.

13. IDEM, Bioethics and Secular Humanism, Philadelphia, Trinity Press International, 1991.

14. IDEM, „Religion, bioethics, and the secular state: Beyond religious and secular fundamentalism", în Notizie di Politeia 26.97:59-79.

15. FuKUYAMA, Francis, The End of History and the Last Man, New York, Free Press, 1992. 
16. IDEM, The Great Disruption, New York, Free Press, 1999.

17. Gutmann, Amy \& ThOMPSON, Dennis, Why Deliberative Democracy?, New Jersey, Princeton University Press, 2004.

18. Humanity+, What is Transhumanism? Transhumanist FAQ, https://whatistranshumanism.org/\#what-is-transhumanism.

19. KANT, Immanuel, The Foundations of the Metaphysics of Morals, transl. L.W. Beck, Indianapolis, Bobbs-Merrill, 1959 (AkademieAusgabe AKIV.393). Preussische Akademie der Wissenschaften (Berlin, de Gruyter, 1902.

20. IDEM, Opus Postumum, ed. Eckart Förster, transl. E. Förster \& M. Rosen, Cambridge University Press, 1993, p.204 (AK XXII, 122-123).

21. KAKU, Michio, Physics of the Future. How Science Will Shape Human Destiny and Our Daily Lives by the Year 2100, Doubleday, 2011.

22. KoJÉve, Alexander, Introduction to the Reading of Hegel, ed. Allan Bloom, trans. J.Nichols, New York, Basic Books, 1969.

23. KuRZWEIL, Ray, The Singularity is Near: When Humans Transcend Biology, New York, Penguin, 2005

24. IDEM, Humanité 2.0. Bible du changement, 2007.

25. LAND, Nick, „Meltdown”, în Fanged Noumena. Collected Writings 1987-2007, ed. Robin MacKay \& Ray Brassier, Urbanomic, Falmouth, 2011.

26. More, Max, Transhumanism. Towards a Futurist Philosophy, 1990, http://www.maxmore.com/transhum.htm.

27. Owen, Judd, Religion and the Demise of Liberal Rationalism, University of Chicago Press, 2001.

28. REDFORD, James, „The Physics of God and the Quantum Gravity Theory of Everything", în Social Science Research Network (SSRN), Sept. 10, 2012.

29. RORTY, Richard, Contingency, Irony, and Solidarity, New York, Cambridge University Press, 1989.

30. IDEM, Objectivity, Relativism, and Truth, New York, Cambridge University Press, 1991.

31. SMITH, Steven D., Foreordained Failure: The Quest for a Constitutional Principle of Religious Freedom, New York, Oxford University Press, 1995.

32. VAtтimo, Gianni, After Christianity, trans. L. D'Isanto, New York, Columbia University Press, 2002.

33. IDEM, The End of Modernity, trans. Jon R. Snyder, Baltimore, Johns Hopkins University Press, 1988. 
34. Zabala, Santiago, „A religion without theists or atheists”, în R. RORTY, G. VATTIMO, The Future of Religion, ed. Santiago Zabala, New York, Columbia University Press, 2005.

35. https://www.christianpost.com/news/christian-transhumanismoffers-an-ethical-transhumanist-alternative-196719/

36. https://blog.petrieflom.law.harvard.edu/2018/08/14/can-anational-conscience-be-gene-edited/

37. www.statnews.com/2018/07/16/crispr-potential-dna-damageunderestimated/ 